\title{
Earthquakes and Economic Outcomes: Does Central Bank Independence Matter?
}

\section{Jeroen Klomp ${ }^{1,2} \cdot$ John Sseruyange ${ }^{3}$}

Published online: 25 August 2020

(C) The Author(s) 2020

\begin{abstract}
This study explores whether the degree of central bank independence influences the economic performance in the period immediately following an earthquake. Earthquakes create a classic monetary policy challenge: how to accommodate the real shock in the short run with the objective of low inflation. The ultimate outcome of this dilemma depends for a large part on the degree of delegation of the monetary powers to an independent central bank and the inflation averseness of the central bank governors. Our main empirical findings clearly indicate that the increase in the inflation rate after an earthquake is significantly smaller when monetary policy is conducted by a more independent central bank. At the same time, countries with an independent central bank are confronted with a wider output gap after an earthquake suggesting a slower economic recovery.
\end{abstract}

Keywords Output gap · Inflation · Central Bank Independence $\cdot$ Earthquakes

JEL Codes E52 $\cdot \mathrm{E} 58 \cdot \mathrm{E} 3 \cdot \mathrm{Q} 54$

\section{Introduction}

One of the main global challenges for sustainable economic development in the next decade is to limit the economic consequences of large-scale natural disasters. Since the 1970s, the damage-related costs of these events have risen dramatically. Record losses of some US $\$ 380$ billion were recorded in 2011, the year of the Tohoku earthquake in

Jeroen Klomp

jeroen.klomp@wur.nl

1 Faculty of Military Sciences, Netherlands Defence Academy, Breda, The Netherlands

2 Section Economics, Wageningen University \& Research, P.O. Box 8130, 6700 EWWageningen, The Netherlands

3 Makerere University, Kampala, Uganda 
Japan, equivalent to $0.9 \%$ of global GDP (Guha-Sapir et al. 2015). It is widely documented in the previous literature that these catastrophes put the short-run macroeconomic performance of many countries mainly under considerable downward pressure since they will severely hit countries' economic growth rates, their external performance, price level, financial system, and fiscal sustainability (see among others Felbermayr and Grösch, 2014; Skidmore and Toya 2002; Noy 2009; Loayza et al. 2012; Lis and Nickel 2009; Noy and Nualsri 2011; Gassebner et al. 2010; Oh and Reuveny 2010; Klomp 2017; Wang 2017).

Because natural disasters seriously challenge the economic performance of a country, it is expected that these events will influence the monetary policy decisions made by the central bank. The most important aim of the monetary authorities in the period after a natural disaster is to stabilize the economy again. However, there is only one concern since natural disasters create a classic monetary policy challenge: how to accommodate the real shock in the short run with the objective of anchoring inflation when these two competing objectives demand opposite policy actions. On the one hand, natural disasters cause a shortfall in the output produced, leading to a temporary negative deviation of the balanced growth path (Felbermayr and Gröschl 2014; Loayza et al. 2012; Klomp 2016; Fomby et al. 2013). To spur economic recovery, the central bank might stimulate aggregate demand by using an expansionary monetary policy. However, loosening the monetary stance at a time when domestic output is temporarily low may risk fuelling inflation. On the other hand, natural disasters raise the marginal costs of domestic producers, creating upward pressure on the price level (Cavallo et al. 2014; Heinen et al. 2019; Parker 2018). To stop the inflation rate from rising any further, central banks should adopt a more contractionary monetary policy. However, by following this policy, the output will depress even more. This dilemma demonstrates that central banks are not able to stimulate the economy and stabilize inflation at the same time after a disaster shock. The optimal policy in the period immediately following a disaster should, therefore, balance this trade-off. Keen and Pakko (2011) evaluate the optimal interest rate response by the Federal Reserve after hurricane Katrina that struck the US economy in 2005. Their findings of a calibrated DSGE model indicate that the optimal monetary policy response should involve raising the short-run nominal interest rate. This contractionary policy is mainly motivated by the anti-inflationary bias of the Federal Reserve, suggesting that the nominal interest rate should respond primarily to higher inflation rather than to lower output. In contrast, several other studies find the opposite results. For instance, White (1997) argues that because the first-round effects of inflation following most disasters are only temporary, local, and concentrated in specific sectors, monetary policy should prioritize growth over low inflation.

Thus, whether monetary policy should be loosened or tightened in the wake of a natural disaster is contested and, theoretically, a priori not directly clear as it depends on many characteristics of the monetary policy followed. One key element in this debate is whether the monetary policy decisions are taken by an independent central bank or contrariwise by a more politically constrained central bank. During the last two decades, many countries have implemented reforms designed to grant their monetary authorities greater independence from direct political influence. It is widely believed that central banks otherwise will give in to pressure from politicians who may be motivated by short-run electoral considerations or may value short-run economic 
expansions highly while discounting the longer-run inflationary consequences of expansionary policies (Walsh 2005). If the ability of politicians to distort monetary policy results in excessive inflation, countries with an independent central bank should experience lower rates of inflation. Indeed, there is voluminous empirical evidence justifying this claim by suggesting that central bank independence (CBI) may be instrumental in realizing low inflation (see Cukierman 2008, Crowe and Meade 2007 and Klomp and De Haan 2010a for summaries). ${ }^{1}$ These central banks can, therefore, build a reputation for credibility, thereby reducing the time-inconsistency problem. In turn, as CBI causes a more contractionary monetary policy that should be reflected in lower output. However, little empirical evidence is found between measures of real economic activity and central bank independence (Alesina and Summers 1993; Pollard 1993). One can, therefore, argue that central bank independence appears to be a free lunch. $^{2}$

Most empirical studies, up so far, are mainly concerned with the long-run impact of central bank independence on the inflation rate or real economic performance. However, in the long-run, the impact of economic shocks is assumed to be zero as they will be averaged out over time. In contrast, the contribution of our study is to explore whether central bank independence is also able to mitigate shocks immediately in the period when they have happened. For this purpose, we use a quasi-experiment in which the frequency of earthquakes is taken as our measure of shocks hitting the economy. According to the extensive literature on retrospective voting, politicians are kept responsible by the electorate for the economic loss created by a natural catastrophe. However, at the same time, voters reward government officials when they react quite promptly by taking decisive actions in the aftermath that will improve economic recovery (i.e., Healy and Malhotra 2009; 2010; Reeves 2011; Garrett and Sobel 2003; Gasper and Reeves 2011). So, this will give politicians a great incentive to stimulate the economy in the aftermath of a disaster by having more expansionary fiscal and monetary policies. ${ }^{3}$ To achieve this, governments might put some considerable political pressure on the central bank in the aftermath of a natural disaster to loosen its monetary policy. However, in countries with an independent central bank, the monetary policy should be resistant to this political pressure (see, for instance, Masciandaro and Passarelli 2019). Consequently, a large part of the disaster impact is absorbed through the reduced output to stabilize the price level in the aftermath in countries with an independent central bank. In turn, in countries with a central bank that is more subject to political interference, it is expected that the output is more stimulated due to electoral considerations resulting in a higher price level in the short run.

Although the empirical evidence on the relationship between CBI and the economic performance after a natural disaster is lacking, there are some classic examples and anecdotes. For instance, the Reserve Bank of New Zealand loosened its monetary

\footnotetext{
${ }^{1}$ In a meta-regression analysis of 57 empirical studies Klomp and De Haan (2010a) conclude first that legal CBI measures have a negative relationship with inflation in OECD countries, especially during the 1980s. Second, studies based on the turnover rate of the central bank governor suggest a positive relationship between this indicator of CBI and inflation in developing countries.

${ }^{2}$ Alternatively, price stability is generally regarded as an essential condition for sustainable economic growth and that central bank independence should accordingly lead to a higher level of economic growth.

${ }^{3}$ This is also confirmed in the empirical literature. For instance, Garrett and Sobel (2003) find that nearly half of all disaster relief payments in the United States are motivated by political rent seeking as opposed to need.
} 
policy in the days after the Canterbury earthquake to stimulate the wider economy. The central bank of New Zealand is recognized as a rather politically dependent central bank since the government still has a considerable influence on central bank objectives. In contrast, in the period before hurricane Katrina, the Federal Reserve (FED) was following a pre-defined path of increasing the funds rate. The hurricane did not alter this contractionary policy. ${ }^{4}$ The FED is regarded as more independent from political interference in setting its policies. ${ }^{5}$

The choice for earthquakes as our indicator of natural disasters is based on a number of reasons. First, these disasters occur rather exogenously as they cannot directly be influenced by human behavior and are not related to the ongoing process of climate change. Second, although earthquakes happen only along the fault lines between two tectonic plates on land or the ocean floor, it is still hard to predict or forecast the timing of an event or develop an effective early warning system. Third, it is difficult to take precautionary measures that reduce the vulnerability of the population for geophysical disasters other than enforcing strict building codes and zoning rules. Fourth, earthquakes are more equally spread across Less Developed Countries (LDCs) and industrialized countries compared to other disasters such as floods or droughts. This reduces the possibility that our empirical results, later on, suffer from a sample selection bias. Finally, compared to other natural disasters, earthquakes have the largest real economic impact. Based on the estimated damage figures reported by EM-DAT, the amount of damage per affected caused by a single earthquake is, on average, about 2.5 times larger than, for instance, for a major flood. Even more, about half of the reported total amount of damage related to natural disasters is attributed to earthquakes (Guha-Sapir et al. 2015).

We estimate a simultaneous equation model, including more than 90 countries between 1975 and 2015. Meanwhile, we construct an exogenous measure on the frequency of geophysical disasters based on the information provided by the "Global Significant Earthquake Database" collected by the National Oceanic and Atmospheric Administration (NOAA). Our most important findings suggest that the increase in the inflation rate is smaller when monetary policy is conducted by a more independent central bank. At the same time, countries with an independent central bank have to deal with a wider output gap after an earthquake compared to countries where the government does not influence the monetary policy. Based on these findings, we can conclude that central banks that are less under political control put more weight on lowering the inflation pressure after an earthquake at the expense of the short-run output. However, it turns out that part of this effect can be explained by several monetary policy characteristics. For instance, central banks that follow a specific monetary policy rule (i.e., fixed exchange rate or inflation targeting) are more likely to adopt a contractionary policy than central banks that have more discrete powers.

The remainder of the paper is organized as follows. In the next section, we discuss our theoretical foundation underlying our hypothesis and review the existing empirical literature on the economic impact of earthquakes. In section three, we describe our data

\footnotetext{
${ }^{4}$ One alternative explanation is that the economic-wide exposure to the damage of the hurricane was limited.

${ }^{5}$ Based on the legal CBI data reported by Garriga (2016), New Zealand has an average CBI value of about 0.3 in our period of analysis, while the score for the US is around 0.5. A higher CBI score indicates more political independence.
} 
and methodology used. In section four, we report our estimation results on the relationship between earthquakes, economic outcomes, and central bank independence. Finally, we end in section five with our conclusion and discussion.

\section{Background}

\subsection{Theoretical Considerations}

The term "central bank independence" (CBI) refers to the freedom of monetary policymakers from direct political influence or government interference in the conduct of policy. More independent central banks are able to set and control their own monetary objectives and are not constrained in the choice of policy instrument applied.

The economic logic behind the delegation of monetary policy to a politically independent central bank has been long theorized in the economic literature. Monetary authorities can provide a temporary boost to the economy by implementing expansionary policies. Because rational agents are aware of this temptation, they will anticipate this policy action. As a result, the economic boost will automatically translate into higher inflation, with no gain in output or employment. One possible solution to remove the inflationary bias associated with the inherent time inconsistency of monetary policy is to delegate this policy to a conservative central bank that is more inflation averse. For this solution to be effective, the delegation must be perceived as credible, and this requires the monetary authority to be politically independent-i.e., able to resist pressures from electorally motivated officials. If the central bank is conservative and the delegation is credible, inflation will be contained at no real cost in terms of output or employment (see also Rogoff 1985; Kydland and Prescott 1977; Barro and Gordon 1983; McCallum 1995; De Haan and Eijffinger 2016; Masciandaro and Romelli 2015).

It is important to realize that in the time inconsistency problem of monetary policy can only be reduced if monetary authority is delegated to an independent and conservative central bank. Conservative means that the central bank is more inflation averse than the government. If the central bank has the same preferences as the government, it will follow the same policies as the government, and independence would not matter (Berger et al. 2001).

In essence, the problem of monetary policy delegation is formulated as a two-stage game between the government and the central bank. In the first stage, the government chooses the institutional design of the central bank. In the second stage, actual monetary and fiscal policies are implemented. However, when monetary policy is delegated to an independent central bank, it might lead to a conflict of interest between the monetary authorities and the central government as the economic objectives are not necessarily aligned. This is, in particular, visible after an adverse supply shock, such as a natural disaster. Supply shocks raise the marginal costs of producers and create production shortages in the short run. In this situation, the government would like to use an expansionary monetary policy to stimulate economic recovery after the shock for electoral reasons. As a result, a large part of the supply shock will be accommodated through a rise in the inflation rate. In turn, the central bank prefers to use a more contractionary policy in the aftermath of a natural disaster in an attempt to keep prices 
stable and low as it is assumed to be more conservative than the government in maintaining low inflation. Thus, a highly independent central bank will absorb the shock mainly through a drop in the output. The outcome of this policy trade-off ultimately depends on the degree of delegation of the monetary powers and the inflation averseness of the central bank governors. ${ }^{6}$

Based on this discussion, we formulate the two hypotheses that will be tested in this study.

$\mathbf{H}_{1}$ : Countries with a more independent central bank have lower inflation rates after an earthquake than countries with a central bank that is largely under political control.

$\mathbf{H}_{2}$ : Countries with a less independent central bank have a smaller output gap after an earthquake than countries with a more independent central bank.

\subsection{Review of the Existing Literature}

In this section, we briefly review the existing empirical evidence related to the impact of natural disasters, and in particular of earthquakes, on economic performance in terms of inflation and output. Most empirical studies on the macroeconomic impact of natural disasters argue that in the short-run, there is a shortfall in production (i.e., Loayza et al. 2012; Klomp 2016; Fomby, 2013; McDermott et al. 2014). ${ }^{7}$ This temporary deviation from the balanced growth path is mainly caused by a drop in the capital-labor ratio and the destruction of technology. For instance, the empirical results provided by Felbermayr and Gröschl (2014) suggest that a natural disaster in the top 1-percentile based on their created damage reduces the same-year GDP per capita by about $6.8 \%$, while the top 5-percentile disasters cause per capita income to drop at least by $0.3 \%$ in the same year of a disaster (see also Lackner 2018). In turn, the key results of the empirical analysis reported by Fisker (2012) demonstrate that while there is no significant effect of an earthquake at the country level, earthquake exposure significantly decreases the economic growth rate at the local level. Regions at lower stages of economic development suffer harder in terms of economic growth than richer areas. Additionally, various event studies explore the real macroeconomic impact of specific earthquakes (DuPont and Noy 2015: 1995 Kobe; Doyle and Noy 2015: 2010 Canterbury; Selcuk and Yeldan 2001: 1999 Turkey; Barone and Mocetti 2014: 1976 and 1980 Italy). The main conclusion that is shared among these case studies is that there is a negative effect of earthquakes on real GDP per capita, at least in the short run.

Moreover, after a natural disaster, the price level within a country is under upward pressure due to a number of reasons. First, the marginal costs of domestic producers increase since there is a shortage of inputs needed in production. Second, the general price level rises as the share of less-competitive imports increases to compensate for the

\footnotetext{
${ }^{6}$ The theoretical prediction regarding the impact of natural disasters on monetary policy are not affected by framing it within a time inconsistency model. For instance, using a New-Keynesian model, Klomp (2020) and Keen and Pakko (2011) show that a natural disaster makes monetary policy more contractionary by raising the policy interest rate. This result is in line with the findings reported throughout this study. In the working paper that is available from this study, we use a stylized analytic model to proof these arguments in a theoretical way. ${ }^{7}$ In the long run the predictions are less clear. Traditional neo-classical growth models predict that the destruction of capital drives countries temporarily away from their balanced-growth path, while the endogenous growth models provide less clear-cut predictions. For example, models based on Schumpeter's creative destruction theory may even predict higher growth rates as disaster shocks can work as an accelerator for upgrading the capital stock (Loayza et al. 2012; Klomp 2016; Klomp and Valckx 2014).
} 
shortage of domestic production. Third, the cost of transportation might rise as goods need to come from abroad or access to some remote areas is very restricted. Finally, a natural disaster may create a situation in which large amounts of aid flows into the country, creating a small or local economic boom, which in turn will lead to an increase in the prices of goods needed in the recovery process.

Nevertheless, the empirical evidence on the inflationary impacts of natural disasters is rather inconclusive. For instance, using data for the Caribbean, Heinen et al. (2019) conclude that extreme weather events create a large upward pressure on aggregate inflation, mainly attributed to the price rises of food and housing. In contrast, Cavallo et al. (2014) examine the impacts of the 2010 Chile and the 2011 Japan earthquake on product availability and prices. The authors find that there are sharp falls in good availability immediately ex-post. Surprisingly, these shortages did not translate into higher prices. Moreover, the results of Doyle and Noy (2015) suggest that the Canterbury earthquake in 2010 caused a drop in the inflation rate due to the fall in aggregate demand. Most evidence up so far is mainly based on case or regional studies. However, one exception is Parker (2018), who uses a large global panel to explore the inflationary effects of natural disasters. His results indicate that the inflation persistence of major natural events is ambiguous and is, for a large part, conditional as it relies on the level of development of a country, the type and strength of the disaster, and the composition of the inflation measure. On earthquakes specific, he reports that these natural events significantly reduce the inflation rate excluding food, housing, and energy in the three years following the disaster. One important explanation for the fall in the inflation rate in the post-earthquake period is that earthquakes are not only able to induce an adverse supply shock, but also a negative demand shock (see also Klomp 2020). For instance, Fratzscher et al. (2020) find that disaster shocks are contractionary and inflationary on impact, followed by a short-lived boom in consumption and investment activity. Thus the source of the change in the inflation rate (demand-pull or cost-push) is likely to affect the response of the monetary authorities.

\section{Data and Methodology}

\subsection{Earthquake and CBI Data}

One of the main challenges in the literature dealing with the macroeconomic impacts of natural disasters is the identification strategy of these events as they are the product of hazard, exposure, and vulnerability (Felbermayr and Gröschl 2014; Yonson et al. 2018). Most scholars agree that a large part of the hazard to a natural event is beyond government control or cannot be affected by the behavior of a single person (exogenous). In contrast, the exposure and vulnerability part of a disaster event, in terms of the number of people affected or physical damage created, depends to some extent on the socio-economic situation or government choices made in the past (Kellenberg and Mobarak 2008; Neumayer et al. 2014). For instance, the total damage created by a disaster is often positively related to the level of income, while the number of people affected is negatively affected by the level of income.

Thus estimating properly, the causal relationship between earthquakes and economic variables requires measures on the disaster impact that do not correlate with those 
disaster outcomes. It is, therefore, essential to separate the exposure and vulnerability element from the impact and focus exclusively on the hazard part. Hence, we should use detailed information about the physical strength of an event. However, for many disasters, especially slow onset events such as droughts, this intensity is rather difficult to observe or is based on a somewhat arbitrary definition. In turn, earthquakes are directly observable, and data on the magnitude are readily available. To be specific, the data on the physical magnitude of earthquakes and their impact are documented in the "Global Significant Earthquake Database" collected by the National Oceanic and Atmospheric Administration (NOAA). This NOAA database has worldwide coverage and contains data for more than three centuries. The dataset includes information about the magnitude, damage scale, location, geographical spread, and whether a tsunami or volcano eruption has followed the earthquake.

Each week more than one hundred earthquakes happen. However, to be included in the dataset, an event should meet at least one of the following two criteria: (1) creates damage (approximately $\$ 1$ million or more); or (2) causes fatalities. By imposing these criteria, it partially controls for the concern that two episodes may have a completely different impact because of their intensity and location. Thus, disasters that occur in the middle of the desert or far from the coastline are not considered as disasters under this measure. These low thresholds guarantee that most earthquakes are recorded, which minimizes the under-reporting bias to a large extent. Nevertheless, many of the disasters recorded in this dataset still cause only a little physical damage. For example, based on the reported figures, only $10 \%$ of the earthquakes recorded worldwide involve damage that is over $1 \%$ of GDP. ${ }^{8}$ Given this distribution of the earthquake magnitude, it is conceivable that minor earthquakes will have only a negligible impact on monetary policy. For a disaster to have an empirical impact, it should be of a magnitude that can directly harm the macroeconomic performance of a country. For this reason, we adopt an additional decision rule that filters out the major earthquakes included based on its intensity. To be specific, in our analysis, later on, we include only events that also satisfy one of the following restrictions (1) the earthquake is at least of magnitude 6.5 on the Richter scale or (2) the Modified Mercalli Intensity scale is greater than IX. ${ }^{9}$ Figure 1 shows that there is a close relationship between the magnitude of an earthquake measured by the Richter scale and the monetary value of the damage reported. This filter leaves us with about 600 major earthquakes between 1975 and 2015. Table 5 in the appendix shows the distribution of events across countries. In total, there are about 63 countries affected by at least one major earthquake in our period of analysis. In about $15 \%$ of the country-years, there is more than one earthquake recorded. Moreover, Fig. 2 illustrates the average number and the mean magnitude of the included events over time. On average, there are about 15 major events yearly, and the average magnitude is around seven on the Richter

\footnotetext{
${ }^{8}$ One needs to interpret these figures carefully as they might be plagued by a number of endogeneity concerns (Felbermayr and Gröschl 2014).

9 We slightly deviate from NOAA's definition of a significant earthquake that is based on a Richter scale of at least 7.5. The reason is that otherwise a substantial number of earthquakes from developing countries that have caused serious damage to the domestic economy would be removed from the sample. So there is a clear tradeoff between the inclusion of earthquakes in our dataset and endogeneity issues since the consequences of an earthquake are for a large part determined by economic and institutional factors.
} 


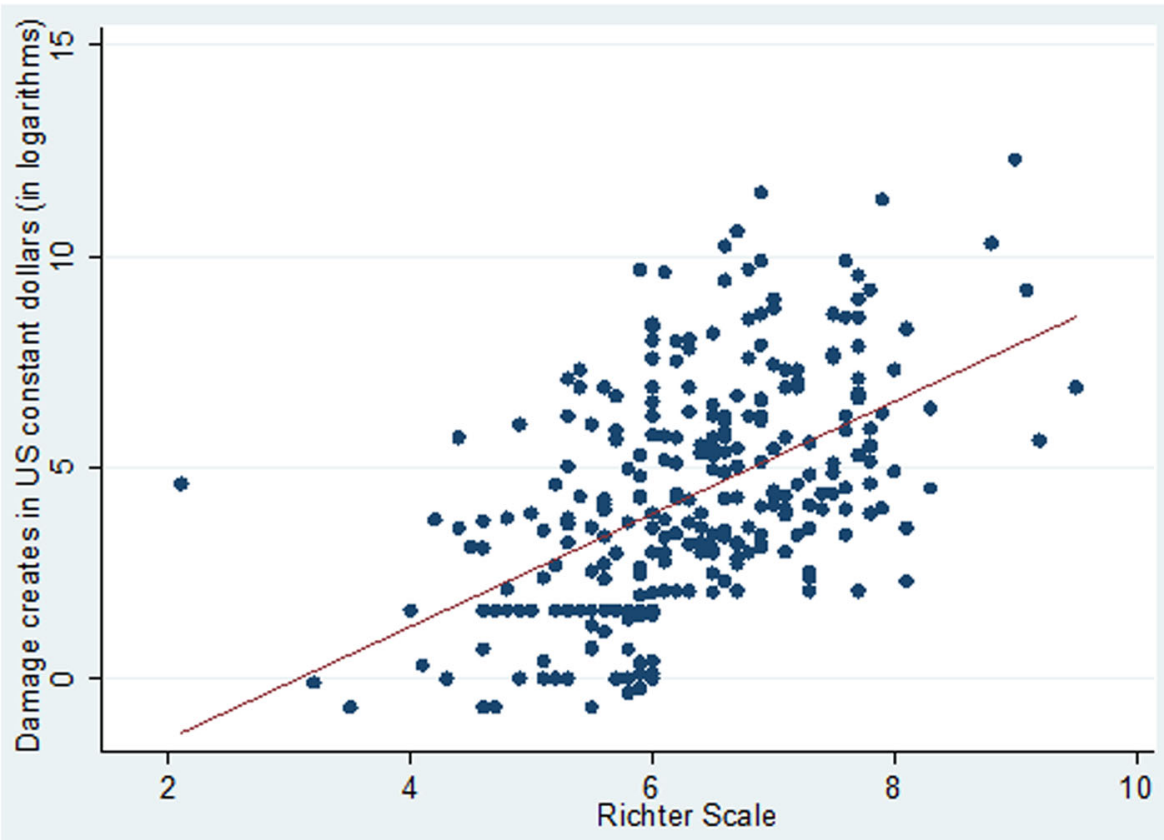

Fig. 1 Correlation between monetary damage and earthquake strength. Based on data provided by NOAA (2016)

scale. In both the frequency and magnitude of events, there is no significant time trend visible in our period of analysis. This supports the exogeneity of the used disaster some further.

To determine the impact of earthquakes on the economic performance, we construct for each country-year an earthquake count variable that takes the timing of an event in the course of a year into account. This allows earthquakes happening at the beginning of the year to have a different impact than those that happen near the end of the year.

$$
E Q_{i t}=\left\{\begin{array}{cc}
\frac{\sum\left(\frac{12-M_{i k t}}{12}\right)+\sum\left(\frac{M_{\text {int }-1}}{12}\right)}{\rho_{i}} & \text { (post)earthquake year } \\
0 & \text { otherwise }
\end{array}\right.
$$

Since the contemporaneous impact of an earthquake within one year is considered, our annual earthquake measure is calculated as the weighted sum of earthquakes $k$ that happened in the current year $t$ and the earthquakes $n$ that occurred in the previous year $t$ - 1 . We weighted this sum by the month $M$ when the respective earthquake happened. That is, we assign the value $(12-M) / 12$ to a disaster year and $M / 12$ to the post-disaster year. ${ }^{10}$ In all other years, its value is set to zero. Using a count measure puts equal weight to the events. This has the advantage of reducing the influence of outlier events

\footnotetext{
${ }^{10}$ As a robustness test, we also have used a dummy instead taking the value one when there was at least one earthquake in a particular country-year and zero otherwise. The findings delivered by this test where almost similar to the results presented throughout this study (detailed results are available upon request).
} 


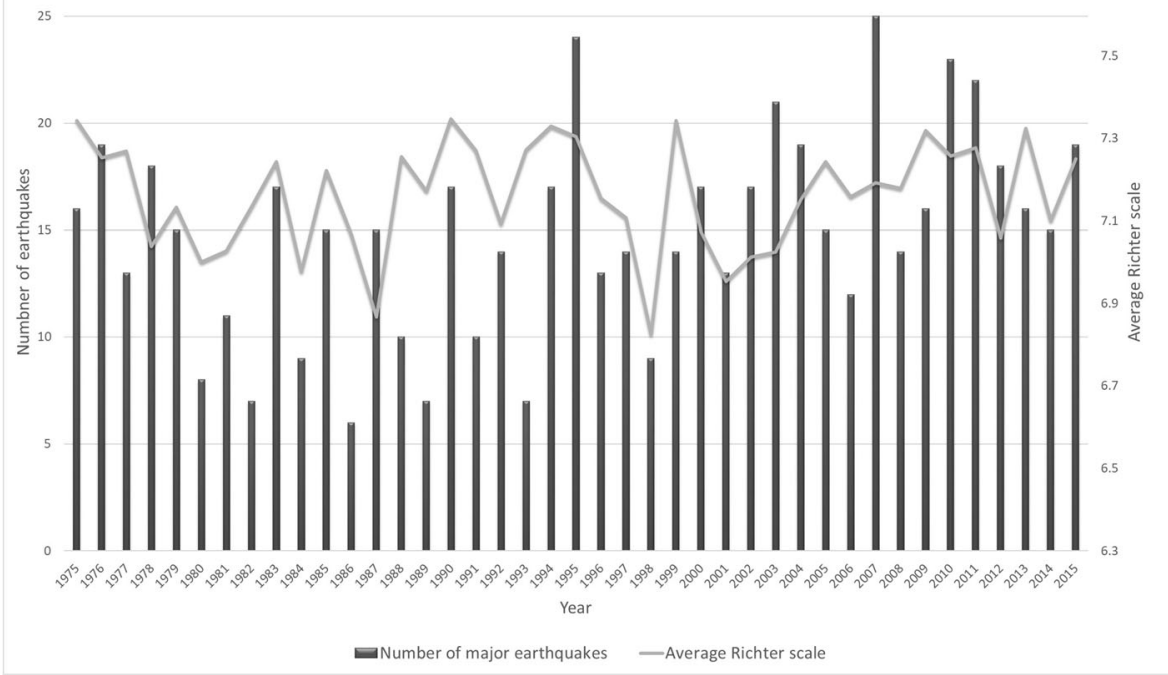

Fig. 2 Number and intensity of major earthquakes. Based on data provided by NOAA (2016)

at the upper end of the distribution. Besides, a country that is hit more than once by a major earthquake in the same year will suffer sharper economic downturns or increases in the inflation rate than a country that suffers only a single incident. We normalize the number of earthquakes by the land area of a country $i$ in $1000 \mathrm{~km}^{2}$, represented by $\rho_{i}$. Obviously, larger countries have a higher probability of experiencing a geophysical event. When, for instance, the United States is hit by an earthquake, the consequences for the economy as a whole are likely to be smaller than when the same earthquake hits Haiti. Especially small island states are extremely vulnerable because of the higher frequency of earthquakes that have a disproportionately large impact on their economy (Skidmore and Toya 2002; Gassebner et al. 2010; Pelling et al., 2002; Freeman et al., 2003; Rasmussen, 2004). ${ }^{11}$

Many empirical studies employing the degree of CBI as their variable of interest base their measures of CBI on the anchoring of political distance in central bank laws and statutes (i.e., Alesina et al. 1989; Cukierman 1992; Grilli et al. 1991). In particular, most de jure CBI indices are based on the methodological approach suggested by Cukierman (1992) by coding the central bank legislation and institutional design on three different dimensions: personnel, financial, and policy independence. However, one concern with legal measures of $\mathrm{CBI}$ is that they may not reflect the true relationship between the central bank and the government in countries where the rule of law is less strongly embedded in the political culture. In these countries, there can be wide gaps

\footnotetext{
${ }^{11}$ When not controlling for the land size, our earthquake measure may be correlated with the error term in our empirical estimation. As a robustness test, we also have used to the total population or total GDP in the previous year as measures to standardize the number of earthquakes. Nevertheless, the main results presented throughout this study are almost unaffected as there is a high and significant correlation between the country size on the one hand and the size of the economy or population size on the other. However, one concern is that the size of the population or economy could be affected by the earthquakes in the past (detailed results are available upon request).
} 
between the formal, legal, institutional arrangements (de jure) and their practical impact (de facto) (Walsh 2005; Bodea and Higashijima 2017). As argued by Hielscher and Markwardt (2012), granting a central bank more legal autonomy does not necessarily lead to better inflation performance. To lower inflation by increasing independence, the quality of the political institutions must be sufficiently high. As the majority of countries in our sample can be classified as low or middle-income countries, this gap between de jure and de facto independence might affect our results. Alternatively, Cukierman et al. (1992) argue that the actual average term in office of the central bank governor may be a better proxy for CBI for these countries than legal measures based on central bank laws. In countries where the central bank is under substantially political influence, it might be easier to fire central bank governors using political pressure. The basic idea behind using the turnover rate of central bank governors as a CBI proxy is based on the presumption that a higher turnover of central bank governors indicates a lower level of independence (see also Pinter (2018) and Klomp and De Haan (2010b)). We use data on the turnover of central bank governors reported by Dreher et al. (2010). The turnover rate is calculated using a rolling window of five years, which is about equal to the median legal term in office of a central bank governor in our dataset. ${ }^{12}$

As a preliminary statistical test, we compute the average difference in the inflation rate and output gap after an earthquake for a sample of countries with an independent bank and countries with a central bank that is under substantial government influence. ${ }^{13}$ According to the $p$ value of this test, the inflation rate is increased to a less extent after an earthquake in countries with an independent central bank. This difference is statistically significant at a $90 \%$ significance level. In contrast, although earthquakes widen the output gap in both CBI samples, there is no significant difference between countries with or without an independent central bank at common significance levels. However, this nonparametric test is only suggestive, as unobserved country heterogeneity, as well as other confounding variables, are not taken into account.

\subsection{Model}

To explore whether the impact of earthquakes on the output and inflation rate relies on the degree of central bank independence, we estimate the following system of two equations. We use a large unbalanced panel dataset, comprising about 90 countries between 1975 to 2015 .

$$
\begin{gathered}
\pi_{i t}=\alpha+\beta_{1} \pi_{i t-1}+\beta_{2} \widehat{y}_{i t}+\beta_{3} E Q_{i t}+\beta_{4} C B I_{i t}+\beta_{5}\left(E Q_{i t} \times C B I_{i t}\right)+\mu_{n} \mathbf{z}_{t-j}+\rho_{t}+\rho_{T}+\varepsilon_{i t} \\
\widehat{y}_{i t}=\gamma+\theta_{1} \widehat{y}_{i t-1}+\theta_{2} \pi_{i t}+\theta_{3} E Q_{i t}+\theta_{4} C B I_{i t}+\theta_{5}\left(E Q_{i t} \times C B I_{i t}\right)+\varphi_{k} \mathbf{x}_{t-q}+\delta_{t}+\delta_{T}+v_{i t}
\end{gathered}
$$

\footnotetext{
${ }^{12}$ Using turnover rates of ten or seven years provides us with similar results.

${ }^{13}$ Based on the median turnover rate of the central bank governors.
} 
The variable $\pi_{i t}$ is the modified inflation rate in the country $i$ in year $t$ computed as $p$ / $(1+p)$ where $p$ is the annual price level change. The transformation of the inflation rate reduces the heteroscedasticity of the error term. The variable $\widehat{y}_{i t}$ is the output gap (as a share of the actual GDP) in the country $i$ in year $t$. To separate the cyclical component from the real GDP per capita series, we apply the Hodrick-Prescott filter. ${ }^{14}$ In particular, the one-sided or backward-looking HP filter is used to overcome the problem that the trend growth in the past is affected by earthquakes from the future. The annual data on the actual inflation rate and GDP is taken from the International Financial Statistics reported by the IMF.

Moreover, the variable $E Q_{i t}$ is our constructed earthquake variable outlined above, capturing the exogenous frequency and exposure of a country to geophysical hazard events. The parameters $\delta_{t}$ and $\rho_{t}$ are year dummies, while $\delta_{T}$ and $\rho_{T}$ are decade dummies. These time fixed effects control for country-invariant unobserved characteristics such as global shifts in inflation rates or international economic crises. Besides, it controls for the general tendency of granting more independence to central banks over the last decades. The variable $C B I$ measures the de facto independence of a central bank based on the indicator described above.

The final parameters $\varepsilon_{i t}$ and $v_{i t}$ are error terms. Moreover, earthquakes affect the inflation rate directly through parameters $\beta_{3}$ and $\beta_{5}$ and indirectly through the impact on the output gap $\beta_{2}$. In turn, earthquakes have a direct influence on the output gap through parameters $\theta_{3}$, and $\theta_{5}$ and more indirectly through the impact on the inflation rate $\theta_{2}$. Thus, to explore the mitigating impact of central bank independence on the economic outcomes after the earthquake, we need to consider the following complete marginal effects

$$
\begin{aligned}
& \frac{\partial \pi}{\partial E Q}=\frac{\partial \pi}{\partial E Q}+\frac{\partial \pi}{\partial \widehat{y}} \frac{\partial \widehat{y}}{\partial E Q}=\beta_{3}+\beta_{5} C B I+\beta_{2}\left[\theta_{3}+\theta_{5} C B I\right] \\
& \frac{\partial \widehat{y}}{\partial E Q}=\frac{\partial \widehat{y}}{\partial E Q}+\frac{\partial \widehat{y}}{\partial \pi} \frac{\partial \pi}{\partial E Q}=\theta_{3}+\theta_{5} C B I+\theta_{2}\left[\beta_{3}+\beta_{5} C B I\right]
\end{aligned}
$$

(4) and (5)

As the equations include the lagged endogenous variable, we estimate eqs. (2) and (3) using the Generalized Method of Moments (GMM) estimator to deal with endogeneity. This estimator does not require information on the exact distribution of the disturbances but is based upon the assumption that the disturbances in the equations are uncorrelated with a set of instrumental variables. In our estimations, the set of instrumental variables of each equation includes all exogenous right-hand side variables of both equations (including country and time dummies). The GMM estimator selects parameters in such a way that the correlations between the instruments and disturbances are as close to zero as possible, as defined by a criterion function. By choosing the

\footnotetext{
$\overline{{ }^{14} \text { We use a smoothing parameter }} \lambda$ of 6.25 as suggested by Ravn and Uhlig (2002).
} 
weighting matrix in the criterion function appropriately, GMM can be made robust to heteroscedasticity and/or autocorrelation of unknown form. In more detail, we apply the two-step system-GMM estimator developed in Arellano and Bover (1995) and Blundell and Bond (1998). In essence, it estimates in a system the regression equations in differences and levels, each with its specific set of instruments. Relative to conventional instrumental variable methods, it improves substantially on the weak instruments problem through more formal checks of the validity of the instruments and provides for potentially improved efficiency. ${ }^{15}$

An important issue is that there are possibly too many instruments relative to the sample size. To avoid this instrument problem, It is possible to limit the number of lags of the instruments used and collapse the instrument matrix in order to achieve this goal. In particular, we use a lag length interval from one up to three years (Roodman, 2009). Additionally, we corrected the potentially downward-biased standard errors with Windmeijer's (2005) finite-sample correction for the asymptotic variance of the twostep GMM estimator.

In selecting control variables, we draw on previous studies. The variables included in vector $\mathbf{z}$ are based on studies that deal with output fluctuations within and between countries, while the controls included in $\mathbf{x}$ are derived from the literature explaining inflation rate differences. To be precise, in eq. (10), we include imports as a share of GDP, a fixed exchange rate dummy, the external debt-to-GDP ratio, and changes in terms of trade as our control variables. In turn, in the vector $\mathbf{x}$ of eq. (11) we add government expenditure (per capita and logarithm), trade openness (import plus export as a share of GDP), level of democracy, domestic private credit (as a share of GDP), capital formation (as a share of GDP), population growth and secondary school enrolment rate as covariates. All control variables are mainly taken from the World Development Indicators or International Country Risk Guide and entered with a lag to control for the simultaneity concerns with our earthquake measure. Table 4 in the Appendix offers a description of all variables used and provides their sources.

\section{Empirical Results}

\subsection{Basic Results}

In Table 1, we report the results of different econometric specifications of the system of equations using the system-GMM estimator. The consistency of the GMM estimator depends on the validity of the instruments. To address this issue, we consider the Hansen statistic of over-identifying restrictions, which tests the overall validity of the instruments. The Hansen test statistic provides no evidence of misspecification. We have normalized the coefficients of the earthquake variable and the corresponding interaction terms by the median country size in our sample to make the interpretation easier. To obtain robust standard errors, we use the bootstrap procedure with 1000

\footnotetext{
${ }^{15}$ As the one-step GMM estimator requires homoskedasticity and uncorrelated error terms to be efficient, we used the asymptotically more efficient two-step estimator. However, as robustness test, we have estimated the main model using the one-step system-GMM estimator and first-difference GMM estimator. Although the magnitude and significance of some of the variables of interest varies, the main conclusions still hold (detailed results are available upon request).
} 
replicators and cluster them at the country level. This reduces, for instance, the possibility that our results are driven by small countries that have an extremely high frequency of earthquakes.

In column (1), we estimate our baseline specification. We can draw a number of conclusions from these results. First, regardless of the degree of independence of a central bank, earthquakes raise the price level significantly within a country and widen the output gap. Second, countries that have a lower turnover rate of central bank governors have a lower inflation rate, while the output gap is not significantly affected by the degree of central bank independence. One rational explanation for this latter finding is that on the one hand, lower inflation rates caused by following a more contractionary policy should lead to lower levels of output. However, on the other hand, a low inflation rate is generally regarded as an essential condition for sustainable economic growth and that central bank independence should accordingly lead to a higher level of economic growth. These two effects apparently cancel each other out. This finding is in line with Alesina and Summers (1993), arguing that CBI in practice is a free lunch. An alternative explanation is that the public in countries with a credible independent central bank has more stable inflation expectations. Third, on the objective of our study, we find that the interaction term between earthquakes and CBI enters statistically significant with a positive sign in the inflation specification. This latter outcome suggests that when the central bank has a larger degree of independence, it will try to limit the additional inflation pressure caused by the earthquake by implementing a more contractionary policy. Finally, following this contractionary policy has probably important consequences for the real macroeconomic performance since the interaction term between CBI and our earthquake indicator has a weak significant positive effect in the output gap regression. This latter implies that countries with an independent central bank have a lower recovery rate.

To interpret these findings, we compute the complete marginal effects as given in eq. (4) and (5) for different quantiles based on turnover rates of the central bank governor. We evaluate these marginal effects by combining the first round inflation (output gap) effects together with the second round output gap (inflation rate) effects. The results presented in Table 2 suggest that an earthquake increases the inflation rate by slightly less than $4 \%$ in countries where the central bank is under serious political influence. In turn, one additional earthquake raises the inflation rate by only $0.8 \%$ in countries where the monetary authorities are rather independent of political influence. For the impact of the output gap, we find the opposite pattern. In countries where the degree of $\mathrm{CBI}$ is high, the output gap widens about $0.3 \%$ more compared to countries with a dependent central bank. Thus, the contractionary policy followed by more independent central banks in the aftermath of an earthquake hampers the short-run economic recovery. These overall mediating effects of CBI are statistically significant for both the inflation rate as well as for the output gap at common confidence intervals. In more detail, about $90 \%$ of this mediating impact in both the inflation and output gap can be attributed to the first-round effect. One critical remark about the results is that although we attribute the effect found on the CBI variable to the degree of independence, it could also well be that this effect is caused by the degree of conservatism of the central bank regarding low and stable inflation rates. That is, we assume that an independent central bank is also more conservative than a central bank that is, for a large part, under government influence. 
Table 1 Earthquakes, CBI and economic outcomes

(1)

(2)

(3)

(4)

\section{Inflation rate regression}

CBI

Earthquakes

$\mathrm{CBI} \times$ Earthquakes

CBI $\times$ Low-income dummy

Earthquakes $\times$ Low-income dummy

$\mathrm{CBI} \times$ Earthquakes $\times$ Low-income dummy

$\mathrm{CBI} \times$ Government spending

Earthquakes $\times$ Government spending

$\mathrm{CBI} \times$ Earthquakes $\times$ Government spending

\section{Output gap regression}

CBI

Earthquakes

$\mathrm{CBI} \times$ Earthquakes

$\mathrm{CBI} \times$ Low-income dummy

Earthquakes $\times$ Low-income dummy

$\mathrm{CBI} \times$ Earthquakes $\times$ Low-income dummy

$\mathrm{CBI} \times$ Government spending

Earthquakes $\times$ Government spending

$\mathrm{CBI} \times$ Earthquakes $\times$ Government spending

Country fixed effects

Additional controls

Arelanno-Bond AR(2) p value

Hansen overidentification test ( $p$ value)

\begin{tabular}{|c|c|c|c|}
\hline $0.201 * *$ & $0.131 * *$ & $0.068^{*}$ & $0.060 *$ \\
\hline$(0.059)$ & $(0.060)$ & $(0.036)$ & $(0.032)$ \\
\hline $0.007 *$ & $0.007 *$ & $0.007 *$ & $0.004 *$ \\
\hline$(0.004)$ & $(0.004)$ & $(0.004)$ & $(0.002)$ \\
\hline $0.035^{* *}$ & $0.014 * *$ & $0.013 *$ & $0.007^{*}$ \\
\hline \multirow[t]{13}{*}{$(0.010)$} & $(0.005)$ & $(0.008)$ & 0.004 \\
\hline & $0.044 * *$ & $0.022 *$ & $0.019^{*}$ \\
\hline & $(0.011)$ & $(0.013)$ & $(0.012)$ \\
\hline & $0.004 *$ & $0.003 *$ & $0.001 *$ \\
\hline & $(0.002)$ & $(0.002)$ & $(0.001)$ \\
\hline & $0.007 *$ & $0.005^{*}$ & $0.002 *$ \\
\hline & $(0.004)$ & $(0.003)$ & $(0.001)$ \\
\hline & 0.007 & 0.005 & 0.004 \\
\hline & $(0.011)$ & (0.004) & $(0.003)$ \\
\hline & 0.019 & 0.014 & 0.014 \\
\hline & $(0.016)$ & $(0.018)$ & $(0.009)$ \\
\hline & 0.001 & 0.001 & 0.001 \\
\hline & $(0.001)$ & $(0.001)$ & $(0.001)$ \\
\hline 0.015 & 0.020 & 0.020 & 0.019 \\
\hline$(0.012)$ & $(0.036)$ & $(0.014)$ & $(0.014)$ \\
\hline$-0.006^{* *}$ & $-0.008 * *$ & $-0.004 *$ & -0.008 \\
\hline$(0.002)$ & $(0.003)$ & $(0.002)$ & $(0.005)$ \\
\hline $0.003 *$ & $0.003 *$ & $0.003 *$ & $0.004 *$ \\
\hline \multirow[t]{13}{*}{$(0.002)$} & $(0.002)$ & $(0.002)$ & $(0.002)$ \\
\hline & 0.008 & 0.005 & 0.007 \\
\hline & $(0.006)$ & $(0.004)$ & $(0.005)$ \\
\hline & $-0.003 *$ & $-0.002 *$ & -0.002 \\
\hline & $(0.002)$ & $(0.001)$ & $(0.001)$ \\
\hline & 0.001 & 0.001 & 0.001 \\
\hline & $(0.001)$ & $(0.001)$ & $(0.001)$ \\
\hline & 0.007 & 0.007 & 0.006 \\
\hline & $(0.005)$ & $(0.005)$ & $(0.004)$ \\
\hline & 0.005 & 0.004 & 0.003 \\
\hline & $(0.008)$ & $(0.003)$ & $(0.002)$ \\
\hline & 0.001 & 0.001 & 0.001 \\
\hline & $(0.001)$ & $(0.001)$ & $(0.001)$ \\
\hline NO & NO & YES & $\mathrm{NO}$ \\
\hline NO & NO & NO & YES \\
\hline 0.649 & 0.595 & 0.557 & 0.508 \\
\hline 0.434 & 0.523 & 0.533 & 0.375 \\
\hline
\end{tabular}

Note: **** Indicating significance levels of respectively 5 and 10\%. Bootstrapped standard errors are shown between brackets 
Table 2 Mitigating effect of CBI

\begin{tabular}{lll}
\hline & Inflation rate & Output gap \\
$\mathrm{CBI}=0.25$ & $0.82 \%^{*}$ & $-0.50 \% *$ \\
$\mathrm{CBI}=0.50$ & $1.66 \% * *$ & $-0.43 \% *$ \\
$\mathrm{CBI}=0.75$ & $3.92 \% * *$ & $-0.20 \% *$ \\
\hline
\end{tabular}

Note: **/* Indicating significance levels of respectively 5 and $10 \%$ of the marginal effects

So far, we have assumed that earthquakes and CBI have a uniform effect across countries. However, the impact of earthquakes and the reaction of the central bank might rely on two important conditions. First, the level of economic development. Poor countries often have a history of high inflation rates, weaker checks and balances, more macroeconomic instability, lower levels of technology and capital, less policy credibility and are more frequently affected by shocks. The impact of earthquakes might, therefore, substantially differ between high and low-income countries. However, the direction of this difference is not immediately clear. On the one hand, low-income countries are more vulnerable to earthquakes due to lower quality buildings and infrastructure. On the other hand, middle and high-income countries have a larger physical capital stock and more high-technological facilities which could be at risk during an earthquake. Meanwhile, it is widely documented in the existing literature that countries with strong adaptive institutional capacities, which are usually particularities of high-income countries, suffer less from the damage of earthquakes than countries with weak institutions (Anbarci et al., 2005; Kahn 2005). Based on the classification provided by the World Bank, we create a dummy to split our sample into low- and high-income countries. Countries with a real GDP lower than 4000 US dollars are identified as low-income countries, while countries with a real GDP per capita above 4000 US dollars are classified as high-income countries. ${ }^{16}$

A second important issue is the response of the fiscal authorities in the aftermath of an earthquake. Governments typically face increased pressure on their public spending as they need to provide emergency assistance and finance the recovery efforts (Lis and Nickel 2010; Melecky and Raddatz 2015; Noy and Nualsri 2011). The reaction of the central bank might rely on the fiscal policy actions taken by the central government to absorb the shock. In particular, the monetary authorities might sterilize or accommodate the fiscal policy based on its main objective. For instance, when a central bank has as its primary goal to have low and stable inflation, it might partly undo the expansionary policies implemented by the national government in the aftermath of an earthquake.

To capture these two issues, we include in column (2) the low-income dummy and the natural logarithm of the government expenditures per capita (in natural logarithms) into the baseline specification together with the interaction terms with our earthquake indicator, CBI measure, and three-way interaction. The results illustrate that in low-income countries, the mediating effect of an independent central bank on the inflation rate shock caused by an earthquake is lower. This implies that at any given turnover rate of the central bank governor, the inflation

\footnotetext{
${ }^{16}$ We have classified countries that are identified by the World Bank as low income and lower-middle income countries as "low-income countries", while countries categorized by the World Bank as upper-middle income countries and high income countries are merged into "high-income countries".
} 
rate is higher after an earthquake in developing countries than in industrialized countries. Moreover, we do not find any significant evidence that there is a different mediating impact of central bank independence on the output gap after an earthquake between high and low-income countries.

On the side of government spending, we find that the reaction of the monetary authorities is independent of the fiscal policy actions taken in the aftermath of an earthquake as any of the interaction terms based on government spending are statistically significant in either the output gap or inflation rate regression at common confidence levels.

In the next analysis, we include country-fixed effects to control for unobserved country-specific characteristics that are time-invariant such as geographical factors. By using a country-specific intercept, we put the emphasis of our analysis on the identification of the within-country variation over time. The findings reported in column (3) of Table 2 indicate that including country-fixed effects reduces the significance of the CBI measure and the corresponding interaction terms. One explanation is that by adding country-fixed effects, the identification is obtained from countries that changed their degree of central bank independence over the period of the analysis and would exclude from the sample countries where the turnover rate is constant. Especially for many highincome countries, the variation in the turnover rate is quite low. Thus, CBI is better able to explain the variance in economic outcomes after an earthquake between countries rather than within countries over time.

However, one concern with the results presented so far is that it might suffer from an omitted variable bias since we have included only a limited number of control variables. As already mentioned above, the inflation rate and output gap are determined by a large number of economic factors. Therefore, in column (4), we estimate our model, including these control variables, suggested in the previous section. The findings indicate that adding covariates leaves the impact of earthquakes almost unaffected. However, one important note is that including the suggested control variables reduces our dataset by about half as there is a trade-off between adding additional variables and country coverage due to missing data.

To summarize, regardless of the econometric specification chosen, there is clear empirical support for our two hypotheses provided above, suggesting that the inflation rate is lower and the output gap is wider after an earthquake when monetary policy is conducted by a more independent central bank. ${ }^{17}$

\subsection{Monetary Strategy}

The effect found so far shows that a more independent central bank tries to offset the inflation pressure caused by an earthquake at the cost of lower output. However, the magnitude of the CBI effect after an earthquake might rely to some extent on the

\footnotetext{
${ }^{17}$ Additionally, we check whether our results are driven by the empirical technique applied. Therefore, we reestimate our main models using one-step GMM method. The conclusions that can be draw when using this alternative estimation methods are very similar to the two-step results.
} 
monetary strategy followed by the policymakers. In the remainder of this section, we try to reveal these mechanisms. In more detail, we estimate the following model

$$
\begin{aligned}
\pi_{i t}= & \alpha+\beta_{1} \pi_{i t-1}+\beta_{2} \widehat{y}_{i t}+\beta_{3} E Q_{i t}+\beta_{4} C B I_{i t}+\beta_{5}\left(E Q_{i t} \times C B I_{i t}\right) \\
& +\delta_{1} \boldsymbol{m}_{\boldsymbol{t}}+\delta_{2}\left(E Q_{i t} \times \boldsymbol{m}_{\boldsymbol{t}}\right)+\delta_{3}\left(C B I_{i t} \times \boldsymbol{m}_{\boldsymbol{t}}\right)+\delta_{4}\left(E Q_{i t} \times C B I_{i t} \times \boldsymbol{m}_{\boldsymbol{t}}\right) \\
& +\mu_{n} \mathbf{z}_{\boldsymbol{t}-\boldsymbol{j}}+\rho_{t}+\varepsilon_{i t} \\
\widehat{y}_{i t}= & \gamma+\theta_{1} \widehat{y}_{i t-1}+\theta_{2} \pi_{i t}+\theta_{3} E Q_{i t}+\theta_{4} C B I_{i t}+\theta_{5}\left(E Q_{i t} \times C B I_{i t}\right) \\
& +\psi_{1} \boldsymbol{m}_{\boldsymbol{t}}+\psi_{2}\left(E Q_{i t} \times \boldsymbol{m}_{\boldsymbol{t}}\right)+\psi_{3}\left(C B I_{i t} \times \boldsymbol{m}_{\boldsymbol{t}}\right)+\psi_{4}\left(E Q_{i t} \times C B I_{i t} \times \boldsymbol{m}_{\boldsymbol{t}}\right) \\
& +\varphi_{k} \mathbf{x}_{\boldsymbol{t}-\boldsymbol{q}}+\delta_{t}+\vartheta_{i t}
\end{aligned}
$$

Where $\boldsymbol{m}$ is a vector containing several dummies representing the monetary strategy followed by a particular central bank. The other variables have the same meaning as in eq. (2) and (3). Countries that follow a particular monetary policy rule might gain more credibility with the public when complying with the rule, but are less flexible in stabilizing supply shocks in the short run. For instance, countries can only maintain a fixed exchange rate when the domestic inflation rate is close to the inflation rate in the foreign country. Ramcharan (2007) finds consistent evidence that flexible exchange rate regimes provide a cushion that ameliorates the disaster's negative impact on growth. Likewise, to gain a credible reputation, central banks that have an explicit inflation target should try to keep the current inflation rate as close as possible to its target level. This latter idea argues that under strict inflation targeting, the supply shock is completely passed on to the adjustment in the actual output, and the inflation rate is unchanged. In particular, Fratzscher et al. (2020) find that inflation targeting improves macroeconomic performance following major natural disasters. It lowers inflation, raises output growth, and reduces inflation variability compared to alternative monetary regimes. Thus, following a specific monetary strategy with a specific target might be used as an alternative to an independent central bank.

In columns (1)-(3) of Table 3, we control for three monetary strategies that can be followed by the central bank: inflation targeting, monetary targeting, or fixed exchange rate. The data on the monetary strategy is mainly based on information taken from the "De Facto Classification of Exchange Rate Regimes and Monetary Policy Framework" reported by the IMF. ${ }^{18}$ A country has a fixed exchange rate when it has a fixed peg, an exchange rate arrangement with no separate legal tender or currency board arrangement. In turn, flexible exchange rate regimes include crawling pegs, managed floats, or independent float. Moreover, countries have an inflation targeting strategy when it publicly announces the medium-term target for inflation with an institutional commitment by the monetary authority to achieve

\footnotetext{
${ }_{18}$ This data is supplemented by information from central banks from individual countries.
} 
these targets. Finally, a monetary targeting strategy involves that the monetary authority uses its instruments to achieve a target growth rate for a monetary aggregate, such as reserve money or the money supply becomes the nominal anchor or intermediate target of monetary policy.

The results suggest that when the central bank has an explicit inflation target or a fixed exchange rate, central bank independence offsets the inflationary impact of earthquakes more compared to countries that do not follow these particular rules. In turn, the impact of an earthquake on the output gap is larger in countries with a central bank that is more constrained in their monetary policy setting, especially when governed by an independent central bank. ${ }^{19}$ Based on these results we can argue that following a specific monetary strategy is not a substitute for central bank independence, but rather a complement as it reinforces the $\mathrm{CBI}$ effect in the aftermath of an economic shock.

\subsection{Magnitude of the Earthquake}

In this robustness section, we perform three tests using alternative measures on the impact of earthquakes. First, in the models presented so far, we include only major earthquakes in our dataset. However, this might lead to a selection bias as we include less than a quarter of the earthquakes reported by NOAA. In the next test, we include all earthquakes that are reported in the NOAA dataset in our period of analysis. The findings in column (4) of Table 3 indicate that CBI has no mitigating effect anymore of the impact of earthquakes on output and the inflation rate. One can, therefore, argue that monetary policy is only affected when the damage created is serious enough to be a threat to the economic performance of a country.

Secondly, we use an alternative major earthquake measure taking into account the Richter scale of the individual earthquake. To capture this issue, we use the following modified formula

$$
E Q_{i t}=\left\{\begin{array}{cc}
\frac{\sum\left(\left(\frac{12-M_{i k t}}{12}\right) \times R_{i k t}\right)+\sum\left(\left(\frac{M_{\text {int }-1}}{12}\right) \times R_{\text {int }}\right)}{\rho_{i}} & \text { (post)earthquake year } \\
0 & \text { otherwise }
\end{array}\right.
$$

Where $R$ is the Richter scale of an earthquake. The findings in column (6) ot Table 3 are almost similar to the results in our main model. In particular, the average Richter scale in the dataset used is about 7.1. Inserting this figure would lead to almost the same economic size of earthquakes.

\footnotetext{
${ }^{19}$ As a robustness test, we have also run the main models from Table 1 without the EMU countries as since the establishment of the European Central Bank (ECB) they have one common monetary policy. However, this does not affect the main results presented throughout this study. We also re-estimated the most important specifications excluding the financial crisis period after 2007. Again, this did not influence our main conclusions (detailed results are available upon request).
} 
Table 3 Monetary strategy and earthquake magnitude

\begin{tabular}{|c|c|c|c|c|c|c|}
\hline & $\begin{array}{l}\text { Inflation } \\
\text { targeting } \\
\text { (1) }\end{array}$ & $\begin{array}{l}\text { Monetary } \\
\text { targeting } \\
\text { (2) }\end{array}$ & $\begin{array}{l}\text { Fixed } \\
\text { exchange } \\
\text { rate } \\
(3)\end{array}$ & $\begin{array}{l}\text { All } \\
\text { earthquakes } \\
\text { (4) }\end{array}$ & $\begin{array}{l}\text { Damage as } \\
\text { share of GDP } \\
\text { (5) }\end{array}$ & $\begin{array}{l}\text { Richter } \\
\text { scale } \\
\text { (6) }\end{array}$ \\
\hline \multicolumn{7}{|l|}{ Inflation rate regression } \\
\hline CBI & $\begin{array}{l}0.161^{*} \\
(0.089)\end{array}$ & $\begin{array}{l}0.172 * \\
(0.104)\end{array}$ & $\begin{array}{l}0.116^{* *} \\
(0.044)\end{array}$ & $\begin{array}{l}0.046^{* * *} \\
(0.019)\end{array}$ & $\begin{array}{l}0.218 * * \\
(0.055)\end{array}$ & $\begin{array}{l}0.248 * * \\
(0.081)\end{array}$ \\
\hline Earthquakes & $\begin{array}{l}0.008^{*} \\
(0.004)\end{array}$ & $\begin{array}{l}0.006^{*} \\
(0.003)\end{array}$ & $\begin{array}{l}0.008 * * \\
(0.003)\end{array}$ & $\begin{array}{l}0.001 \\
(0.002)\end{array}$ & $\begin{array}{l}0.001 * \\
(0.001)\end{array}$ & $\begin{array}{l}0.001 * \\
(0.000)\end{array}$ \\
\hline $\mathrm{CBI} \times$ Earthquakes & $\begin{array}{l}0.026^{*} \\
(0.015)\end{array}$ & $\begin{array}{l}0.024 * \\
(0.014)\end{array}$ & $\begin{array}{l}0.025 * * \\
(0.011)\end{array}$ & $\begin{array}{l}0.011 \\
(0.008)\end{array}$ & $\begin{array}{l}0.011 * \\
(0.006)\end{array}$ & $\begin{array}{l}0.005 * * \\
(0.001)\end{array}$ \\
\hline $\begin{array}{l}\text { CBI } \times \text { Monetary } \\
\text { strategy }\end{array}$ & $\begin{array}{l}-0.032 \\
(0.048)\end{array}$ & $\begin{array}{l}0.021 \\
(0.025)\end{array}$ & $\begin{array}{l}-0.015 \\
(0.029)\end{array}$ & & & \\
\hline $\begin{array}{l}\text { Earthquakes } \times \\
\text { Monetary strategy }\end{array}$ & $\begin{array}{l}-0.002 * \\
(0.001)\end{array}$ & $\begin{array}{l}0.002 \\
(0.002)\end{array}$ & $\begin{array}{l}-0.001 * \\
(0.001)\end{array}$ & & & \\
\hline $\begin{array}{r}\mathrm{CBI} \times \text { Earthquakes } \times \\
\text { Monetary strategy }\end{array}$ & $\begin{array}{l}-0.005^{*} \\
(0.003)\end{array}$ & $\begin{array}{l}-0.007 \\
(0.006)\end{array}$ & $\begin{array}{l}-0.006 * * \\
(0.002)\end{array}$ & & & \\
\hline \multicolumn{7}{|l|}{ Output gap regression } \\
\hline CBI & $\begin{array}{l}0.014 \\
(0.012)\end{array}$ & $\begin{array}{l}0.015 \\
(0.026)\end{array}$ & $\begin{array}{l}0.015 \\
(0.015)\end{array}$ & $\begin{array}{l}0.004 \\
(0.003)\end{array}$ & $\begin{array}{l}0.012 \\
(0.021)\end{array}$ & $\begin{array}{l}0.019 \\
(0.020)\end{array}$ \\
\hline Earthquakes & $\begin{array}{l}-0.006^{*} \\
(0.003)\end{array}$ & $\begin{array}{l}-0.005^{* *} \\
(0.003)\end{array}$ & $\begin{array}{l}-0.008^{* * *} \\
(0.002)\end{array}$ & $\begin{array}{l}-0.001 \\
(0.002)\end{array}$ & $\begin{array}{l}-0.002 * \\
(0.001)\end{array}$ & $\begin{array}{l}0.004 * * \\
(0.004)\end{array}$ \\
\hline $\mathrm{CBI} \times$ Earthquakes & $\begin{array}{l}0.002 * \\
(0.001)\end{array}$ & $\begin{array}{l}0.003 \\
(0.003)\end{array}$ & $\begin{array}{l}0.002 * * \\
(0.001)\end{array}$ & $\begin{array}{l}0.001 \\
(0.001)\end{array}$ & $\begin{array}{l}0.001 * \\
(0.000)\end{array}$ & $\begin{array}{l}-0.001 * \\
(0.001)\end{array}$ \\
\hline $\begin{array}{l}\text { CBI } \times \text { Monetary } \\
\text { strategy }\end{array}$ & $\begin{array}{l}-0.003 \\
(0.005)\end{array}$ & $\begin{array}{l}-0.002 \\
(0.001)\end{array}$ & $\begin{array}{l}-0.002 \\
(0.002)\end{array}$ & & & \\
\hline $\begin{array}{l}\text { Earthquakes } \times \\
\text { Monetary strategy }\end{array}$ & $\begin{array}{l}0.001 \\
(0.002)\end{array}$ & $\begin{array}{l}0.001 \\
(0.001)\end{array}$ & $\begin{array}{l}0.001 * \\
(0.001)\end{array}$ & & & \\
\hline $\begin{array}{r}\mathrm{CBI} \times \text { Earthquakes } \times \\
\text { Monetary strategy }\end{array}$ & $\begin{array}{l}-0.001^{*} \\
(0.000)\end{array}$ & $\begin{array}{l}-0.001 \\
(0.001)\end{array}$ & $\begin{array}{l}-0.001 * * \\
(0.000)\end{array}$ & & & \\
\hline $\begin{array}{l}\text { Arelanno-Bond } \mathrm{AR}(2) \mathrm{p} \\
\text { value }\end{array}$ & 0.583 & 0.883 & 0.519 & 0.661 & 0.596 & 0.617 \\
\hline $\begin{array}{l}\text { Hansen overidentification } \\
\text { test ( } p \text { value) }\end{array}$ & 0.675 & 0.657 & 0.624 & 0.693 & 0.599 & 0.399 \\
\hline
\end{tabular}

Note: **/* Indicating significance levels of respectively 5 and 10\%. Estimated using the model specification reported in column (2) of Table 1. Bootstrapped standard errors are shown between brackets 
Finally, so far, we did not take directly into account the size of damage created by an earthquake since this is, to a large part, endogenous. As explained in the data section, the amount of damage depends not only on the hazard risk, but also on the exposure and vulnerability of a country to earthquakes. This implies that two events, similar in the Richter scale, may create more or less damage depending on the level of economic development. To explore whether our results would differ when using a measure that is based on the damage created, we use the total physical damage caused by an earthquake (as a share of GDP in the previous year and taken in logarithm) as an alternative measure. ${ }^{20}$ The estimation results are in column (5) of Table 3. The findings show the same pattern as before. Central bank independence reduces the inflation rate shock, but at the same time, weakly widens the output gap. However, these results should be interpreted with care since they might be plagued by endogeneity. For instance, doubts have been expressed about the accuracy of the data on the consequences of natural disasters. That is, estimates are probably more accurate in rich countries compared to poor countries, as inflating the numbers will result in more foreign aid assistance in the near future (Strobl 2012). Also, for a substantial number of earthquakes in our sample, the damage information is missing.

\section{Conclusion}

Due to the major adverse impact of earthquakes on the aggregate production and price level of a country, it is expected that these events will influence the monetary policy decisions taken by the central bank. The main aim of the monetary authorities in the period following a disaster is to stabilize the economy again. However, there is one problematic concern since these events create a classic monetary policy challenge: how to accommodate the real shock in the short run with the objective of anchoring inflation. These two competing objectives demand opposite policy actions. When monetary policy is delegated to an independent central bank, it might lead to a conflict of interest between the monetary authorities and the central government as the economic objectives are not always aligned. In this situation, the government pushes the use of the monetary policy to stimulate economic recovery after the shock for electoral reasons, while the central bank prefers to use this policy in an attempt to stabilize the economy again. Thus, whether monetary policy should be loosened or tightened in the wake of a natural disaster is contested and, theoretically, a priori not directly clear as it depends on many characteristics of the monetary policy followed. One key element in this debate is whether the monetary policy decisions are made by an independent central bank or contrariwise by a more politically constrained central bank.

\footnotetext{
${ }^{20}$ Consequently, the $\log$ is taken to avoid that the empirical results are driven by extreme values. In order to retain as much observations as possible, we follow Loayza et al. (2012) by assigning country-years for which no event occurred a low number that is just below the lowest positive earthquake measure since the log of zero is undefined.
} 
Our contribution to the literature is to explore empirically whether, and if so, to what extent, the degree of central bank independence determines the economic outcomes - in terms of inflation and output - after an earthquake. After extensive testing for the sensitivity of the results, our most important findings suggest that the inflation rate is lower, and the output gap is wider after an earthquake when monetary policy is conducted by a more independent central bank. That is, countries with more politically constrained central banks put more weight on lowering the inflation pressure after an earthquake at the expense of the short-run output. However, it turns out that this impact is partly explained by a conditional effect. For instance, central banks that follow a certain policy rule more often adopt a contractionary monetary policy to fight the inflation pressure. This effect is, in particular, visible when the central bank is liberated from political influence.

We would like to thank the three anonymous reviewers for their helpful comments and suggestions which have greatly improved this study.

\section{Appendix}

Table 4. Data used.

\begin{tabular}{|c|c|c|}
\hline Variable & Definition & Source \\
\hline Imports & Imports of goods and services as a share of GDP & $\begin{array}{l}\text { World Development } \\
\text { Indicators }\end{array}$ \\
\hline Terms of trade & The net barter terms of trade in logarithms & $\begin{array}{l}\text { World Development } \\
\text { Indicators }\end{array}$ \\
\hline Fixed exchange rate & $\begin{array}{l}\text { Dummy variable taking the value one when a country } \\
\text { has a fixed exchange rate }\end{array}$ & IMF \\
\hline $\begin{array}{l}\text { Government } \\
\text { expenditure }\end{array}$ & $\begin{array}{l}\text { General government final consumption expenditure as a } \\
\text { share of GDP }\end{array}$ & $\begin{array}{l}\text { World Development } \\
\text { Indicators }\end{array}$ \\
\hline External debt & External debt as a share of GDP & $\begin{array}{l}\text { World Development } \\
\text { Indicators }\end{array}$ \\
\hline Trade openness & $\begin{array}{l}\text { Sum of exports and imports of goods and services } \\
\text { as a share of GDP }\end{array}$ & $\begin{array}{l}\text { World Development } \\
\text { Indicators }\end{array}$ \\
\hline Private credit & Domestic credit to private sector as a share of GDP & $\begin{array}{l}\text { World Development } \\
\text { Indicators }\end{array}$ \\
\hline $\begin{array}{l}\text { Secondary school } \\
\text { enrolment }\end{array}$ & Gross secondary school enrolment & Barro and Lee (2010) \\
\hline Population growth & Growth rate of the total population & $\begin{array}{l}\text { World Development } \\
\text { Indicators }\end{array}$ \\
\hline Capital formation & Gross capital formation as a share of GDP & $\begin{array}{l}\text { World Development } \\
\text { Indicators }\end{array}$ \\
\hline Level of democracy & Polity IV score & Polity IV \\
\hline
\end{tabular}


Table 5 Distribution of the earthquakes

\begin{tabular}{|c|c|c|c|}
\hline COUNTRY & \# earthquakes & COUNTRY & \# earthquakes \\
\hline AFGHANISTAN & 8 & KYRGYZSTAN & 2 \\
\hline ALGERIA & 2 & MEXICO & 20 \\
\hline ARGENTINA & 2 & MOZAMBIQUE & 1 \\
\hline ARMENIA & 1 & MYANMAR (BURMA) & 6 \\
\hline AUSTRALIA & 5 & NEPAL & 4 \\
\hline AUSTRIA & 1 & NEW CALEDONIA & 2 \\
\hline AZERBAIJAN & 1 & NEW ZEALAND & 16 \\
\hline BOLIVIA & 2 & NICARAGUA & 1 \\
\hline CANADA & 2 & PAKISTAN & 5 \\
\hline CHILE & 32 & PANAMA & 4 \\
\hline CHINA & 19 & PAPUA NEW GUINEA & 24 \\
\hline COLOMBIA & 9 & PERU & 17 \\
\hline CONGO & 2 & PHILIPPINES & 25 \\
\hline COSTA RICA & 4 & PORTUGAL & 1 \\
\hline CUBA & 1 & ROMANIA & 3 \\
\hline DOMINICAN REPUBLIC & 2 & RUSSIA & 32 \\
\hline ECUADOR & 6 & SAMOA & 6 \\
\hline EGYPT & 1 & SERBIA AND MONTENEGRO & 1 \\
\hline EL SALVADOR & 3 & SOLOMON ISLANDS & 28 \\
\hline FIJI & 5 & SUDAN & 2 \\
\hline GEORGIA & 1 & TAIWAN & 12 \\
\hline GREECE & 12 & TAJIKISTAN & 1 \\
\hline GUATEMALA & 8 & TANZANIA & 1 \\
\hline HAITI & 1 & TONGA & 8 \\
\hline HONDURAS & 1 & TRINIDAD AND TOBAGO & 1 \\
\hline ICELAND & 2 & TURKEY & 9 \\
\hline INDIA & 10 & TURKMENISTAN & 1 \\
\hline INDONESIA & 82 & USA & 35 \\
\hline IRAN & 18 & UZBEKISTAN & 4 \\
\hline ITALY & 2 & VANUATU & 14 \\
\hline JAPAN & 63 & VENEZUELA & 1 \\
\hline KAZAKHSTAN & 2 & & \\
\hline
\end{tabular}

Open Access This article is licensed under a Creative Commons Attribution 4.0 International License, which permits use, sharing, adaptation, distribution and reproduction in any medium or format, as long as you give appropriate credit to the original author(s) and the source, provide a link to the Creative Commons licence, and indicate if changes were made. The images or other third party material in this article are included in the article's Creative Commons licence, unless indicated otherwise in a credit line to the material. If material is not included in the article's Creative Commons licence and your intended use is not permitted by statutory regulation or exceeds the permitted use, you will need to obtain permission directly from the copyright holder. To view a copy of this licence, visit http://creativecommons.org/licenses/by/4.0/. 


\section{References}

Alesina A, Summers LH (1993) Central bank independence and macroeconomic performance: some comparative evidence. J Money, Credit Banking 25(2):151-162

Alesina A, Mirrlees J, Neumann MJM (1989) Politics and business cycles in industrial democracies. Econ Policy 4(8):57-98

Arellano M, Bover O (1995) Another look at the instrumental variable estimation of error-components models. J Econ 68(1):29-51

Barone G, Mocetti S (2014) Natural disasters, growth and institutions: a tale of two earthquakes. J Urban Econ 84:52-66

Barro RJ, Gordon DB (1983) Rules, discretion and reputation in a model of monetary policy. J Monet Econ 12(1):101-121

Berger H, De Haan J, Eijffinger SC (2001) Central bank independence: an update of theory and evidence. J Econ Surv 15(1):3-40

Blundell R, Bond S (1998) Initial conditions and moment restrictions in dynamic panel data models. J Econ 87(1):115-143

Bodea C, Higashijima M (2017) Central Bank Independence and fiscal policy: incentives to spend and constraints on the executive. Br J Polit Sci 47(1):47-70

Cavallo A, Cavallo E, Rigobon R (2014) Prices and supply disruptions during natural disasters. Rev Income Wealth 60(S2):449-471

Crowe C, Meade EE (2007) The evolution of central bank governance around the world. J Econ Perspect 21(4):69-90

Cukierman A (1992) Central bank strategy, credibility, and independence: theory and evidence (p. 393). MIT press, Cambridge

Cukierman A, Web SB, Neyapti B (1992) Measuring the independence of central banks and its effect on policy outcomes. World Bank Econ Rev 6(3):353-398

Cukierman A (2008) Central bank independence and monetary policymaking institutions - past, present and future. Eur J Polit Econ 24(4):722-736

Doyle L, Noy I (2015) The short run nationwide macroeconomic effects of the Canterbury earthquakes. N Z Econ Pap 49(2):134-156

Dreher A, Sturm JE, De Haan J (2010) When is a central bank governor replaced? Evidence based on a new data set. J Macroecon 32(3):766-781

duPont IV W, Noy I (2015) What happened to Kobe? A reassessment of the impact of the 1995 earthquake in Japan. Econ Dev Cult Chang 63(4):777-812

De Haan, J., \& Eijffinger, S. C. (2016). The politics of central bank independence. Mimeo

Guha-Sapir D, Below R, Hoyois P (2015) EM-DAT: International disaster database. Catholic University of Louvain, Brussels

Felbermayr G, Gröschl J (2014) Naturally negative: the growth effects of natural disasters. J Dev Econ 111: 92-106

Fisker, P. (2012). Earthquakes and economic growth, development research working paper series no. 01/2012

Fomby T, Ikeda Y, Loayza NV (2013) The growth aftermath of natural disasters. J Appl Econ 28(3):412-434

Garrett TA, Sobel RS (2003) The political economy of FEMA disaster payments. Econ Inq 41(3):496-509

Garriga AC (2016) Central Bank Independence in the world: a new data set. Int Interactions 42(5):849-868

Gasper JT, Reeves A (2011) Make it rain? Retrospection and the attentive electorate in the context of natural disasters. Am J Polit Sci 55(2):340-355

Gassebner M, Keck A, Teh R (2010) Shaken, not stirred: the impact of disasters on international trade. Rev Int Econ 18(2):351-368

Grilli V, Masciandaro D, Tabellini G (1991) Political and monetary institutions and public financial policies in the industrial countries. Econ Policy 6(13):341-392

Healy A, Malhotra N (2009) Myopic voters and natural disaster policy. Am Political Sci Rev 103:387-406

Heinen A, Khadan J, Strobl E (2019) The Price impact of extreme weather in developing countries. Econ J 129(619):1327-1342

Hielscher K, Markwardt G (2012) The role of political institutions for the effectiveness of central bank independence. Eur J Polit Econ 28:286-301

Kahn M (2005) The death toll from natural disasters: the role of income, geography, and institutions. Rev Econ Stat 87:271-284

Keen B, Pakko M (2011) Monetary policy and natural disasters in a DSGE model. South Econ J 77:973-990 
Kellenberg D, Mobarak A (2008) Does rising income increase or decrease damage risk from natural disasters? J Urban Econ 63(3):788-802

Klomp J, De Haan J (2010a) Inflation and central Bank Independence: a meta-regression analysis. J Econ Surv 24(4):593-621

Klomp J, De Haan J (2010b) Central bank independence and inflation revisited. Public Choice 144(3-4):445-457

Klomp J (2016) Economic development and natural disasters: a satellite data analysis. Glob Environ Chang 36:67-88

Klomp J (2017) Flooded with debt. J Int Money Financ 73:93-103

Klomp, J. (2020). Do natural disasters affect monetary policy? A quasi-experiment of earthquakes. Forthcoming Journal of Macroeconomics

Kydland FE, Prescott EC (1977) Rules rather than discretion: the inconsistency of optimal plans. J Polit Econ 85(3):473-491

Lackner, S. (2018). Earthquakes and economic growth. FIW working paper 190. Research Centre International Economics, Vienna

Lis EM, Nickel C (2010) The impact of extreme weather events on budget balances. Int Tax Public Financ 17(4):378-399

Loayza NV, Olaberria E, Rigolini J, Christiaensen L (2012) Natural disasters and growth: going beyond the averages. World Dev 40(7):1317-1336

Masciandaro D, Romelli D (2015) Ups and downs of central bank independence from the great inflation to the great recession: theory, institutions and empirics. Financial History Rev 22(3):259-289

McCallum, B. T. (1995). Two fallacies concerning central bank independence. NBER working paper w5075. National Bureau of Economic Research

McDermott TK, Barry F, Tol RS (2014) Disasters and development: natural disasters, credit constraints, and economic growth. Oxf Econ Pap 66(3):750-773

Melecky M, Raddatz C (2015) Fiscal responses after catastrophes and the enabling role of financial development. World Bank Econ Rev 29(1):129-149

Neumayer E, Plümper T, Barthel F (2014) The political economy of natural disaster damage. Glob Environ Chang 24:8-19

NOAA (2016). National Geophysical Data Center / world data service (NGDC/WDS): significant earthquake database. National Geophysical Data Center

Noy I (2009) The macroeconomic consequences of disasters. J Dev Econ 88(2):221-231

Noy I, Nualsri A (2011) Fiscal storms: public spending and revenues in the aftermath of natural disasters. Environ Dev Econ 16(01):113-128

Oh CH, Reuveny R (2010) Climatic natural disasters, political risk, and international trade. Glob Environ Chang 20(2):243-254

Parker M (2018) The impact of disasters on inflation. Econ Disasters Climate Change 2(1):21-48

Pollard, P. (1993). Central Bank Independence and Economic Performance St Louis FED Review 75

Ramcharan R (2007) Does the exchange rate regime matter for real shocks? Evidence from windstorms and earthquakes. J Int Econ 73:31-47

Ravn MO, Uhlig H (2002) On adjusting the Hodrick-Prescott filter for the frequency of observations. Rev Econ Stat 84(2):371-376

Reeves A (2011) Political disaster: unilateral powers, electoral incentives, and presidential disaster declarations. J Polit 73(4):1142-1151

Rogoff K (1985) The optimal degree of commitment to an intermediate monetary target. Q J Econ 100(4): 1169-1189

Selcuk F, Yeldan E (2001) On the macroeconomic impact of the august 1999 earthquake in Turkey: a first assessment. Appl Econ Lett 8(7):483-488

Skidmore M, Toya H (2002) Do natural disasters promote long-run growth? Econ Inq 40(4):664-687

Strobl E (2012) The economic growth impact of natural disasters in developing countries: evidence from hurricane strikes in the central American and Caribbean regions. J Dev Econ 97(1):130-141

Walsh, C. (2005). Monetary theory and policy. MIT press

White B (1997) Preparing for natural disaster - where does the reserve Bank fit in? Reserve Bank Bulletin 60(4):332-341

Yonson R, Gaillard J, Noy I (2018) The measurement of disaster risk: an example from tropical cyclones in the Philippines. Rev Dev Econ 22(2):736-765

Publisher's Note Springer Nature remains neutral with regard to jurisdictional claims in published maps and institutional affiliations. 